\title{
External pancreatic response to food and its relation to the maximal secretory capacity in $\operatorname{dog}{ }^{1}$
}

\author{
F. W. HENRIKSEN AND H. WORNING \\ From the Institute for Experimental Research in Surgery, University of Copenhagen, the Central \\ Laboratory, Blegdamshospitalet, Copenhagen, and the Medical Department P, Rigshospitalet, \\ Copenhagen, Denmark
}

Few attempts have been made to investigate the normal pancreatic response to the stimulus of a meal (Annis and Hallenbeck, 1951; Cooke, Nahrwold, and Grossman, 1967). This may depend upon difficulties in obtaining physiological conditions during the investigation (Gregory, 1962). A comparison between the physiological pancreatic response to food and to exogenous stimuli has, to our knowledge, not been carried out. In the present investigation we have tried to study the pattern of the pancreatic response to food during conditions as close as possible to normal physiological conditions. The secretory rates thus obtained were compared with the maximal secretory capacity of the gland, determined as recently described (Henriksen, 1968).

The secretory rates were compared with the secretion rates following stimulation with secretin or pancreozymin in an attempt to estimate the endogenous release of secretin and pancreozymin during digestion of the meal.

\section{MATERIAL AND METHODS}

Four mongrel dogs were used (body weight 19 to $20 \mathrm{~kg}$ ). In three of the dogs (nos. 64-208, 64-224, and 65-231) a modified Thomas cannula (1941) was inserted into the duodenum exactly opposite the main pancreatic duct. The last dog (no. 65-201) was operated upon by the technique described by Preshaw and Grossman (1965), allowing for collection of the pancreatic juice from a duodenal pouch. The accessory pancreatic duct was ligated and a Thomas cannula was inserted into the stomach at the most dependent part in all the dogs. The dogs were used in experiments after a recovery period of at least three weeks.

The dogs were kept alive for 11 to 47 months. They all remained in a good nutritional state, without loss of weight. At the end of the investigations, the dogs were sacrificed. A pancreatograph through the main pan-

'This work has been supported by grants from the Danish State Research Foundation and the Danish Foundation for the Advancement of Medical Science. creatic duct showed that the ductal system was normal in all dogs, as was the pancreas.

During the experiments the dogs were standing in a sling harness. The gastric cannula was opened in all basal periods, and in the experiments using exogenous stimulation, to prevent gastric juice from entering the duodenum. In the three dogs with Thomas fistulas a glass catheter connected to a glass syringe by a short polyvinylchloride tube was inserted into the main pancreatic duct through the duodenal Thomas cannula. The dependent plunger of the syringe exerted a slightly negative pressure. The dead space of the collecting system was $0.4 \mathrm{ml}$. The pancreatic juice from the dog with the duodenal pouch was collected through a metal cannula. The dead space of this collecting system was $0.7 \mathrm{ml}$, the volume of the pouch not included.

During the feeding experiments the duodenal cannula was closed by a rubber diaphragm through which the glass catheter and a polyethylene tube were led, through which a bicarbonate solution ( $120 \mathrm{~m}$-equiv/l.) was infused into the duodenum opposite the opening of the pancreatic duct, synchronously with and equal to the amount of bicarbonate secreted by the pancreas. In dog no. 64-208 four experiments were performed without simultaneous infusion of bicarbonate into the duodenum.

Except for small amounts of water, the dogs were fasted for 18 hours before the experiments, and the fasting (basal) secretion was collected for at least two periods of 15 minutes each. After the basal period the dogs were given a meal composed of $400 \mathrm{~g}$ of boiled pork hearts, cut in lumps and freed from all visible fat. The meal was eaten in one to two minutes. The pancreatic juice was collected in 10-minute periods during the first hour, and in 10 or 20-minute periods during the subsequent hours. The total period of collection was ordinarily between two-and-a-half and three hours. In some experiments the pancreatic catheter slid out, but usually it was replaced within a few minutes. The mean secretion rate in such periods was calculated from the amounts secreted in the rest of the period. If the catheter had been removed for more than a few minutes the result for that period was discarded.

In the three dogs with Thomas fistulas the maximal secretory capacity of the pancreatic gland was determined by combined stimulation with secretin ${ }^{2}$ and pan${ }^{2}$ Boots Pure Drug Co., Nottingham, England. 
creozymin $^{1}$ (Henriksen, 1968) as single rapid injections into a peripheral vein. Secretin was given as 6 Crick, Harper, and Raper units/kg body weight (CHR-U/kg body weight) in all dogs, and was combined with pancreozymin, varying in doses from 6 to 12 Ivy dog units $/ \mathrm{kg}$ body weight (ID-U/kg body weight). Two to four observations were made at each dose level to determine the maximal secretory capacity. In dogs nos. 64-208, 64-224, and 65-231 the entire dose-response curves for secretin and pancreozymin respectively were determined.

The volume of the pancreatic secretion and the concentration of bicarbonate and protein in the samples were measured. The total concentration of $\mathrm{CO}_{2}$ was determined according to Van Slyke's manometric method (Van Slyke and Neill, 1924), and is referred to as 'bicarbonate'. The concentration of protein was estimated spectrophotometrically at $280 \mathrm{~nm}$ after appropriate dilution of the samples with Sørensen phosphate buffer $p \mathrm{H} \mathrm{6 \cdot 8}$. The extinction values were converted to concentrations of protein by means of a factor empirically determined through Kjeldahl analysis on pooled canine pancreatic juice.

\section{RESULTS}

A different technique for obtaining pancreatic juice was used in dog no. 65-201, and results were compared with the results from the other three dogs. If no significant difference was observed, a mean value common to all dogs was calculated.

The effect of a synchronous infusion of bicarbonate into the duodenum on the pancreatic response after ingestion of a meal is illustrated in Table $I$. The secretion rates for fluid and bicarbonate were significantly higher when no bicarbonate was instilled. The protein secretion was independent of the infusion.

${ }^{1}$ Cholecystokinin-pancreozymin was obtained from Professor E. Jorpes and Dr V. Mutt, Stockholm, Sweden.

\section{TABLE I}

PANCREATIC SECRETION RATE AFTER INGESTION OF A MEAT MEAL BY DOG NO. $64-208$

\begin{tabular}{|c|c|c|c|c|}
\hline & & $A^{1}$ & $B$ & $\mathrm{p}^{3}$ \\
\hline Volume & $\mathrm{m}^{2}$ & 0.68 & $1 \cdot 12$ & $<0.05$ \\
\hline$(\mathrm{ml} / \mathrm{min})$ & $n$ & 7 & 4 & \\
\hline Bicarbonate & $\mathrm{m}$ & 81 & 139 & $<0.05$ \\
\hline ( $\mu$-equiv/min) & $\mathrm{n}$ & 7 & 4 & \\
\hline $\begin{array}{l}\text { Protein } \\
(\mathrm{mg} / \mathrm{min})\end{array}$ & $\mathrm{m}$ & $8 \cdot 6$ & $8 \cdot 6$ & n.s. \\
\hline
\end{tabular}

${ }^{1}$ Group A: sodium bicarbonate solution (120 m-equiv/l) infused into the duodenum synchonously with the juice secreted. Group B: no bicarbonate infusion

${ }^{2} \mathrm{~m}=$ mean of observations in the period $30-180 \mathrm{~min}$.

$\mathrm{n}=$ number of observations

${ }^{3} \mathbf{p}=$ probability of difference between secretion rates

The secretion rates for fluid, bicarbonate, and protein in different periods after ingestion of the meal are shown in Table II. The results for two representative experiments are shown in Figs. 1 and 2 , where it can be seen that the secretion of all components increased above basal level within five to 10 minutes after the ingestion of the meal.

The secretion rates for fluid and bicarbonate were significantly lower in the first $\mathbf{3 0}$ minutes than in the subsequent 150 minutes, when they usually remained at a constant level (Table II). Between 180 and 240 minutes the secretion rate decreased slightly.

The secretion rate for protein was significantly higher in dog no. 65-201 $(\mathrm{P}<0.01)$ than in the remaining dogs (Table II). The highest secretion rates in all dogs were observed in the period 0-30 minutes, after which they remained at a lower level (Table II), but apart from this period, the rate was remarkably constant (Figs. 1 and 2).

In the individual dog, the pancreatic response varied considerably from experiment to experiment (Table III), but the pancreatic secretion was main.

TABLE II

PANCREATIC SECRETION RATES OF FLUID, BICARBONATE, AND PROTEIN IN THE PERIOD 0-180 MINUTES AFTER INGESTION OF A MEAT MEAL

\begin{tabular}{|c|c|c|c|c|c|c|c|c|c|c|c|c|c|}
\hline \multirow[b]{2}{*}{ Dog No. } & \multirow[b]{2}{*}{ Minutes } & \multicolumn{4}{|c|}{ Volume (ml/min) } & \multicolumn{4}{|c|}{ Bicarbonate ( $\mu$-equiv/min) } & \multicolumn{4}{|c|}{ Protein (mg/min) } \\
\hline & & $0-30$ & $30-60$ & $60-120$ & $120-180$ & $0-30$ & $30-60$ & $60-120$ & $120-180$ & $0-30$ & $30-60$ & $60-120$ & $120-180$ \\
\hline \multirow[t]{2}{*}{$64-208$} & $\mathrm{~m}^{1}$ & $0 \cdot 39$ & 0.64 & 0.73 & 0.66 & 37 & 76 & 87 & 75 & $9 \cdot 5$ & $8 \cdot 6$ & $9 \cdot 1$ & 8.5 \\
\hline & $\mathrm{n}$ & 6 & 7 & 5 & 4 & 6 & 7 & 5 & 4 & 4 & 6 & 5 & 4 \\
\hline \multirow[t]{2}{*}{$64-224$} & $\mathrm{~m}$ & 0.53 & 0.89 & 1.00 & 1.06 & 62 & 119 & 136 & 143 & $10 \cdot 3$ & $9 \cdot 3$ & $9 \cdot 6$ & $10 \cdot 0$ \\
\hline & $\mathrm{n}$ & 7 & 7 & 5 & 4 & 7 & 7 & 5 & 4 & 5 & 7 & 5 & 4 \\
\hline \multirow[t]{2}{*}{$65-201$} & $\mathrm{~m}$ & 0.63 & 0.84 & 0.76 & 0.77 & 71 & 105 & 92 & 98 & $14 \cdot 1$ & 10.9 & 8.7 & 9.5 \\
\hline & $\mathrm{n}$ & 8 & 8 & 2 & 1 & 8 & 8 & 2 & 1 & 4 & 4 & 2 & 1 \\
\hline \multirow[t]{2}{*}{$65-231$} & m & 0.51 & 0.71 & 0.57 & 0.43 & 61 & 93 & 72 & 54 & 10.7 & 7.9 & $7 \cdot 3$ & 5.9 \\
\hline & $\mathbf{n}$ & 5 & 6 & 5 & 3 & 5 & 6 & 5 & 3 & 5 & 6 & 4 & 1 \\
\hline \multicolumn{2}{|c|}{$\begin{array}{l}\text { All } \\
\text { (weighted mean) }\end{array}$} & 0.52 & 0.77 & 0.77 & 0.75 & 59 & 99 & 98 & 94 & $10 \cdot 2^{2}$ & $8 \cdot 6^{2}$ & $8 \cdot 8^{2}$ & 8.92 \\
\hline
\end{tabular}




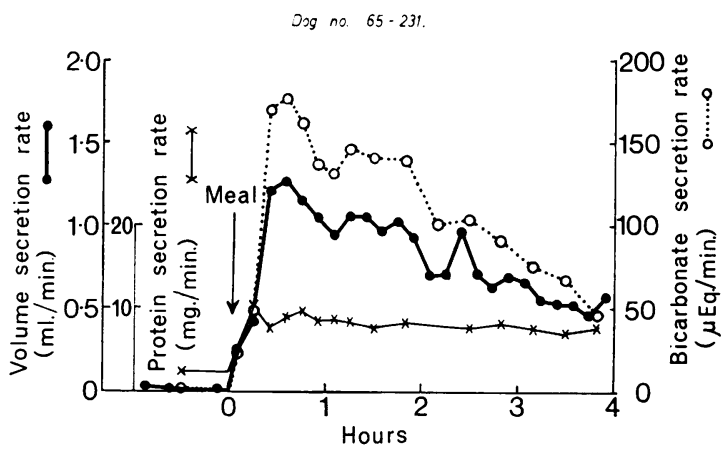

FIG. 1 .

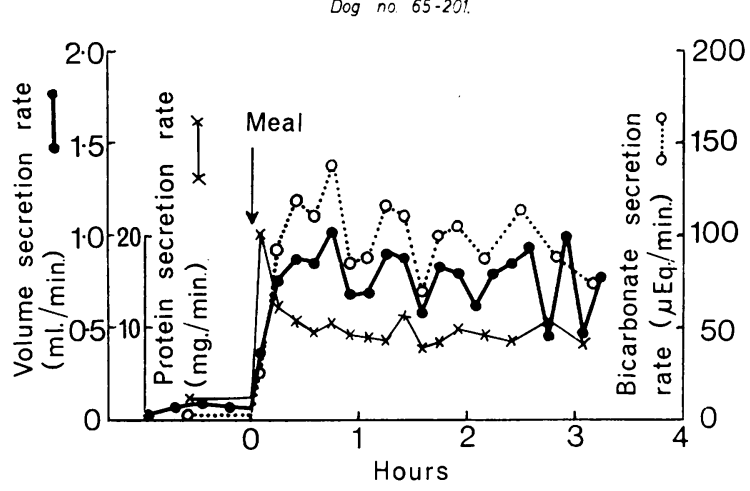

FIG. 2.

FIGS. 1-2. The pattern of pancreatic secretion of fluid, bicarbonate, and protein in response to ingestion of a meat meal.

tained at a relatively constant level. The secretion rate for protein showed smaller variations than did those for fluid and bicarbonate (Table III). The concentration of bicarbonate in the pancreatic juice was highly reproducible (Table III).

The peak secretion rates for fluid and bicarbonate, $i e$, the highest secretion rate obtained in any 10minute period occurred at different periods after ingestion of a meal. In $12 \%$ of the experiments the peak occurred in the first 30 minutes, in $75 \%$ between 30 and 180 minutes. The peak secretion of protein was, however, observed in the first 10 minutes after the ingestion of the meal in all experiments.

The individual peak secretion rates and the mean secretion rates between 30 and 180 minutes following the intake of food were compared to the maximal secretion rates after combined exogenous stimulation (Table IV). On average, the mean secretion rates for fluid and bicarbonate amounted to $37 \%$ of the maximal rate and the protein secretion rate to $21 \%$ of the maximal secretion rate. The peak secretion rate was roughly double the mean secretion rate.
The maximal secretory capacity was not attained in any experiment.

In an attempt to calculate the endogenous release of secretin and pancreozymin in the postprandial period, the mean secretion rates for fluid, bicarbonate, and protein after ingestion of the meal were compared with the secretion of fluid and bicarbonate in the first 10 minutes after isolated stimulation with secretin, and to the secretion of protein in the 10 minutesafter isolated stimulation with pancreozymin. The figures in Table $\mathrm{V}$ are calculated by intrapolation on the dose-response curves for secretin and pancreozymin. As evaluated from the secretion rates, the endogenous release of secretin and of pancreozymin was equal to $0 \cdot 3-1.0$ CHR-U of secretin/ $\mathrm{kg}$ body weight and to $0 \cdot 1-0 \cdot 6$ ID-U of pancreozymin/kg body weight (Table V).

\section{DISCUSSION}

Essential in the present investigation is whether the secretory pattern observed equals the actual secre-

TABLE III

VARIATION IN PANCREATIC MEAN SECRETION RATES AND MEAN BICARBONATE CONCENTRATION IN THE PERIOD 30-180 MINUTES AFTER INGESTION OF FOOD

\begin{tabular}{|c|c|c|c|c|c|}
\hline \multirow[b]{2}{*}{ Dog No. } & & \multicolumn{3}{|c|}{ Secretion Rates } & \multirow{2}{*}{$\begin{array}{l}\text { Bicarbonate } \\
\text { Concentration }\end{array}$} \\
\hline & & Volume & Bicarbonate & Protein & \\
\hline \multirow[t]{2}{*}{$64-208$} & $v^{1}$ & $32 \cdot 1$ & $40 \cdot 6$ & $13 \cdot 6$ & $13 \cdot 2$ \\
\hline & $n$ & 7 & 7 & 7 & 7 \\
\hline \multirow[t]{2}{*}{$64-224$} & $v$ & $14 \cdot 1$ & $15 \cdot 1$ & 10.6 & $2 \cdot 3$ \\
\hline & $n$ & 7 & 7 & 7 & 7 \\
\hline \multirow[t]{2}{*}{$65-201$} & $\mathbf{v}$ & $40 \cdot 1$ & $47 \cdot 5$ & $12 \cdot 3$ & $12 \cdot 3$ \\
\hline & $\mathbf{n}$ & 8 & 8 & 4 & 8 \\
\hline & n & 6 & 6 & 6 & 6 \\
\hline
\end{tabular}

${ }^{1} \mathrm{v}=$ cosficient of variation $(\mathrm{SD} \times 100 /$ mean)

$\mathrm{n}=$ number of observations 
TABLE IV

PANCREATIC SECRETION RATES IN THE 30-180 MINUTES AFTER INGESTION OF A MEAT MEAL AND THE PEAK SECRETION RATES COMPARED WITH THE MAXIMAL SECRETORY CAPACITY

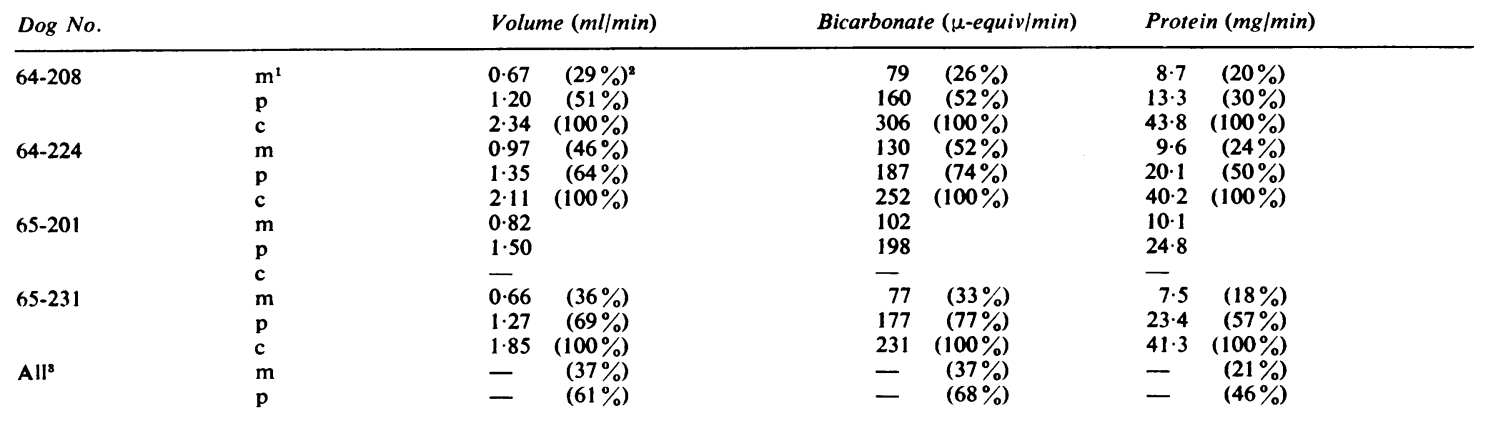

${ }^{1} \mathrm{~m}-$ mean of all observations in the period 30-180 minutes

$\mathrm{p}=$ peak secretory rate (10 minutes)

$c=$ maximal secretory capacity

${ }^{2} \mathrm{~m}$ and $\mathrm{p}$ calculated as a percentage of $\mathrm{c}$

Dog no. 65-201 not included

TABLE V

CALCULATED ENDOGENOUS RELEASE OF SECRETIN AND PANCREOZYMIN AFTER INGESTION OF A MEAT MEAL

\begin{tabular}{|c|c|c|c|}
\hline \multirow[b]{2}{*}{ Dog No. } & \multicolumn{2}{|l|}{ Secretin ${ }^{1}$} & \multirow{2}{*}{$\begin{array}{l}\text { Pancreozymin }^{2} \\
\text { Protein } \\
\text { Secretion }\end{array}$} \\
\hline & $\begin{array}{l}\text { Fluid } \\
\text { Secretion }\end{array}$ & $\begin{array}{l}\text { Bicarbonate } \\
\text { Secretion }\end{array}$ & \\
\hline $64-208$ & 0.5 & 0.5 & 0.4 \\
\hline $64-224$ & 0.8 & $1 \cdot 0$ & 0.6 \\
\hline $65-231$ & 0.3 & 0.3 & 0.1 \\
\hline Mean & 0.5 & 0.6 & 0.4 \\
\hline
\end{tabular}

${ }^{1}$ Crick, Harper, Raper units/kg body weight

${ }^{z}$ Ivy dog units/kg body weight

tion under normal physiological conditions. The surgical procedures did not damage the pancreatic gland as proven by the postmortem investigation. Interductal anastomosis are present in the dog between the accessory and the main duct system (Nielsen and Bishop, 1954). When the accessory duct is ligated, as in the present investigation, the secretion of juice through the main duct will be quantitative if the interductal anastomoses are sufficient and no other accessory ducts are present. Postmortem pancreatography excluded the existence of other accessory ducts. The normal appearance of the pancreas indicated that the interductal anastomoses were sufficient to prevent fibrosis, secondary to the ligation of the accessory duct. The collection of pancreatic juice through the catheter in the main pancreatic duct was considered quantitative, as this was the case in the investigations with exogenous stimulation of the pancreas.

Diversion of the pancreatic juice from the duodenum after ingestion of a meal induces increased secretion of fluid and bicarbonate from the pancreas but has no influence on the secretion of protein (Annis and Hallenbeck, 1951; Cooke et al, 1967, Table I). The secretion obtained when the secreted pancreatic juice (Annis and Hallenbeck, 1951; Cooke et al, 1967) or an equivalent amount of bicarbonate is instilled into the duodenum must be considered normal, as the instillation secures a normal $p \mathrm{H}$ and $\mathrm{PCO}_{2}$ in the duodenal lumen.

The decrease in proteolytic digestion in the duodenum by excluding the pancreatic enzymes from the duodenum may involve a decreased stimulation of the protein secretion (Wang and Grossman, 1951). However, Cooke et al (1967) demonstrated that the protein secretion following ingestion of a meal was independent of whether the pancreatic juice was replaced in the duodenal lumen or not.

It seems justified therefore to conclude that the secretory pattern obtained was very close to the actual secretion under normal physiological conditions.

No difference was observed in the secretion rates of fluid and bicarbonate in the dog operated on after the method described by Preshaw and Grossman (1965) and those supplied with a Thomas cannula. However, the secretion rate of protein was significantly higher in the dog supplied with a duodenal pouch (no. 65-201). This may be explained by the finding of Preshaw and Knauf (1966) who reported the duodenum to secrete a proteolytic enzyme with pepsin-like activity in response to the stimulus of food.

Cooke et al (1967) recently reported on the pancreatic response to food in dogs with duodenal pouches. In spite of a different technique and different amounts of food, the pattern and the secretion rates 
of fluid and bicarbonate in the present investigation were almost identical to those observed by Cooke et al (1967). However, the mean secretion rate of protein was about three times as high in the material of Cooke $e t$ al as in the present investigation. This difference cannot be explained by the additional protein contained in the duodenal juice (Table II, dog no. 65-201). It is due to a different standardization of the analytical methods. In both investigations the concentration of protein was estimated spectrophotometrically at wavelength $280 \mathrm{~nm}$. In the present material a standard solution of pooled canine juice was used, whereas Cooke et al employed bovine serum albumin as a standard. An estimate of the extinction values at $280 \mathrm{~nm}$ for solutions with identical concentrations of protein- $\mathrm{N}$ showed the extinction coefficient for canine pancreatic juice to be three times that for bovine serum albumin. By using this substance as standard, the protein concentration in canine pancreatic juice will be estimated to three times the actual concentration.

The secretion rates for fluid and bicarbonate were significantly lower in the initial 30 minutes than in the subsequent 150 minutes. This is in accord with results obtained with continuous stimulation with secretin (Baron, Perrier, Janowitz, and Dreiling, 1963; Preshaw, Cooke, and Grossman, 1966a) where steady state secretion was reached in about 15 to 60 minutes after stimulation was started.

The protein secretion reached the highest values in the initial 30 minutes in all the dogs (Table II). The same applied to secretion after sham feeding (Preshaw, Cooke, and Grossman, 1966b) and after stimulation with secretin (Delcourt, 1961; Preshaw et al, 1966a). The fact is explicable as a 'washout' phenomenon. In the subsequent period, the secretion rate for protein was remarkably constant, and to a certain degree independent of the secretion rates for fluid and bicarbonate (Figs. 1 and 2). The gastric secretion of acid after ingestion of a meal of the type applied here is equal to the maximal secretion obtainable with histamine (Rune and Henriksen, 1967). The results presented here clearly indicate that pancreatic secretion after ingestion of a meal is far from maximal (Table IV). The mean secretion rates for fluid and bicarbonate were about one third of the maximal obtainable, whereas that for protein amounted to about $20 \%$ of the maximal level. The secretion rate varied considerably from day to day in the individual dog (Table III), but not even the individual peak secretion rates attained the maximal secretion level (Table IV).

The figures for calculated endogenous release of secretin and pancreozymin after ingestion of a meal (Table IV) must be taken with some reservations. Single injections and not a continuous infusion of secretin and pancreozymin were used for the comparison, and the potentiation between secretin and pancreozymin (Henriksen and Worning, 1967) was not taken into account in the calculations.

\section{SUMMARY}

In four dogs the pancreatic secretion of fluid, bicarbonate, and protein after ingestion of a meat meal has been studied under conditions closely similar to those occurring in the normal postprandial period.

The secretion rates for fluid and bicarbonate were lower in the initial 30 minutes than in the subsequent two-and-a-half hours, in which they usually remained at a constant level. The secretion rate for protein was highest in the initial 30 minutes, probably on account of a 'washout' phenomenon, and remained at a constant, but lower level in the subsequent two-anda-half hours. Secretion varied considerably from day to day in the individual dog, with the least variation in the bicarbonate concentration. The secretion rate for protein showed smaller variations than did the secretion rates for fluid and bicarbonate.

The mean secretion rates for fluid and bicarbonate were about one third of the maximal secretion rates obtainable with combined stimulation with secretin and pancreozymin. The mean secretion rate for protein attained one fifth of the maximal rate.

A guarded estimate of the endogenous release of secretin and pancreozymin was attempted.

\section{REFERENCES}

Annis, D., and Hallenbeck, G. A. (1951). Effect of excluding pancreatic juice from duodenum on secretory response of pancreas to a meal. Proc. Soc. exp. Biol. (N.Y.), 77, 383-385.

Baron, J. H., Perrier, C. V., Janowitz, H. D., and Dreiling, D. A (1963). Maximal alkaline (bicarbonate) output of the dog pancreas. Amer. J. Physiol., 204, 251-256.

Cooke, A. R., Nahrwold, D. L., and Grossman, M. I. (1967). Diversion of pancreatic juice on gastric and pancreatic response to a meal stimulus. Ibid., 213, 637-639.

Delcourt, A. (1961). Les modificateurs de la sécrétion exocrine du pancréas et leur action sur les activités enzymatiques sanguines d'origine pancréatique. Ann. Soc. roy. Sci. med. nat. Brux., 14, 193-277.

Gregory, R. A. (1962). Secretory Mechanisms of the Gastrointestinal Tract, pp. 134-142. Arnold, London.

Henriksen, F. W. (1968). The maximal pancreatic secretion in dogs. Scand. J. Gastroenterol., 3, 140-144.

creozymin on the external pancreatic secretion in dogs. Acta physiol. scand., 70, 241-249.

Nielsen, S. W., and Bishop, E. J. (1954). The duct system of the canine pancreas. Amer. J. vet. Res., 15, 266-271.

Preshaw, R. M., Cooke, A. R., and Grossman, M. I. (1966a). Quantitative aspects of response of canine pancreas to duodenal acidification. Amer. J. Physiol., 210, 629-634.

- - _ - (1966b). Sham feeding and pancreatic secretion in the dog. Gastroenterology, 50, 171-178.

by extracts of the pyloric gland area of the stomach. Ibid., 48, 36-44.

- - and Knauf, R. S. (1966). The effect of sham feeding on the secretion and mobility of canine duodenal pouches. Ibid., 51, 193-199. 
Rune, S. J., and Henriksen, F. W. (1967). Secretory rate of gastric acid and pancreatic bicarbonate in the dog after feeding Ibid. 52, 930-939.

Thomas, J. E. (1941). An improved cannula for gastric and intestinal fistulas. Proc. Soc. exp. Biol. (N.Y.), 46, 260-261.

Van Slyke, D. D., and Neill, J. M. (1924). The datermination of gases in blood and other solutions by vacuum extraction and manometric measurement. J. biol. Chem., 61, 523-573.

Wang, C. C., and Grossman, M. I. (1951). Physiological determination of release of secretin and pancreozymin from intestine of dogs with transplanted pancreas. Amer. J. Physiol., 164, 527-545. 